\title{
Analysis of the Influence of Nucleotomy on Lumbar Degeneration of the Operated Level Using the Finite Element Method
}

\author{
Sonlu Eleman Yöntemi Kullanılarak Nükleotominin Ameliyat Edilen \\ Seviyede Lomber Dejenerasyon Üzerine Etkisinin Analizi
}

\author{
Honglei DOU ${ }^{1}$, Shujie TANG ${ }^{2}$ \\ ${ }^{1}$ Yidu Central Hospital of Weifang, Department of Orthopaedics, Qingzhou, Shandong Province, China \\ 2Jinan University, Medical College, Department of Traditional Chinese Medicine, Guangzhou, China
}

Corresponding Author: Honglei DOU / E-mail: douhl2009@163.com

\begin{abstract}
AIM: To determine whether nucleotomy may aggravate lumbar degeneration at the operated level.

MATERIAL and METHODS: A normal healthy finite element model, two degeneration models and corresponding nucleotomy models of the L4-5 segment were created. Combined with $800 \mathrm{~N}$ preloading, $10 \mathrm{Nm}$ moment was applied on the L4 superior endplate to simulate extension, flexion, left axial rotation and lateral bending, respectively. The shear stress of annulus fibrosus, posterior annulus bulge along with the contact force of facet joint at L4-5 were investigated.

RESULTS: In all loading directions, the shear stress and contact force of the facet joint in two nucleotomy models were higher than those in mildly or moderately degenerative models, while the posterior annulus bulge was lower than those in mildly or moderately degenerative models.
\end{abstract}

CONCLUSION: Nucleotomy may adversely aggravate lumbar degeneration at the operated level

KEYWORDS: Nucleotomy, Posterior annulus bulge, Contact force of facet joint, Shear stress, Finite element analysis

öz

AMAÇ: Nükleotominin ameliyat edilen düzeyde lomber dejenerasyonu arttırıp, arttırmadığını belirlemek.

YÖNTEM ve GEREÇLER: L4-5 segmenti için normal sağlıklı bir sonlu eleman modeli, iki dejenerasyon modeli ve karşılık gelen nükleotomi modelleri oluşturuldu. $800 \mathrm{~N}$ ön yükleme ile kombine edilerek L4 superior uç plakasına sırasıyla ekstansiyon, fleksiyon, sol aksiyal rotasyon ve lateral bükülmeyi simüle etmek üzere $10 \mathrm{Nm}$ moment uygulandı. L4-5 üzerinde annulus fibrozus üzerine kırpma stresi, posterior annulus kabarması ve faset ekleminde temas gücü incelendi.

BULGULAR: Tüm yükleme yönlerinde kırpma ve faset ekleminde temas gücü iki nükleotomi modelinde hafif veya orta derecede dejeneratif modellerden daha yüksekken posterior annulus kabarması hafif veya orta derecede dejeneratif modellerden daha düşüktü.

SONUÇ: Nükleotomi, ameliyat edilen düzeyde lomber dejenerasyon üzerine olumsuz etki yapabilir

ANAHTAR SÖZCÜKLER: Nükleotomi, Posterior annulus kabarması, Faset eklemi temas gücü, Kayma gerilimi, Sonlu eleman analizi

\section{INTRODUCTION}

Nucleotomy is a common surgical procedure in the treatment of disc herniation and the space of nucleus pulposus will be replaced by granulation tissues after surgery $(4,10,14)$, resulting in increased stiffness, decreased elasticity $(1,6)$ and changed biomechanics at the operated level. Clinically, the disc space height decreases significantly after nucleotomy with time $(5,8)$, and may decrease the lordosis of the lumbar spine and affect stress conduction (13), indicating aggravated degeneration of the lumbar segment. Consequently, nucleotomy may affect lumbar degeneration at the operated level adversely, but no articles have been published in English on the subject.
Clinical research and conventional experiments have inherent limitations to study the effect of nucleotomy on lumbar degeneration. For instance, the specimens for cases and controls as well as subsequent repetitive testing are difficult to obtain (12). In addition, nucleotomy is usually performed in the degenerative intervertebral disc, but the grade of disc degeneration is difficult to standardize in clinical research and conventional experiments. However, the finite element method is of high reproducibility and repeatability. The models can be adjusted to change the material properties, and imitate both normal and degenerative conditions (13). In the finite element study from Rohlmann (7), different grades of disc degeneration including mild, moderate and 
severe degeneration were simulated by varying disc height and bulk modulus of the nucleus pulposus, which cannot be performed in a clinical study or conventional experiment and demonstrates the advantages of finite element techniques.

Therefore, we created a normal finite element model, two degenerative models and corresponding nucleotomy models of L4-5, to determine if nucleotomy can affect lumbar degeneration at the operated level.

\section{MATERIAL and METHODS}

A three-dimensional finite element model of the L4-5 segment was developed and implemented using ANSYS 10.0. Five different models were considered in the current study, including one normal model, one mild degeneration model, one moderate degeneration model, and corresponding nucleotomy models. The normal model has been validated in previous studies (13). The two degenerative and corresponding nucleotomy models were developed according to the normal model. Clinically, nucleotomy is rarely performed in severe degeneration discs, so we did not analyze the severe degeneration and corresponding nucleotomy model in the current study.

\section{Normal Model}

A three-dimensional finite element model of L4-5 was developed according to the computed tomography scan of a 26-year-old healthy young man (13). The finite element model consisted of intervertebral discs, vertebra, superior and inferior facets, endplates, ligaments and capsules (Figure 1).

The model consisted of 101723 elements. The vertebrae and intervertebral disc were meshed using eight-node solid 186 elements and the spinal ligaments using 2-node link 10 elements. The intervertebral disc consisted of nucleus pulposus and annulus fibrosus. The nucleus pulposus, which was modeled as incompressible material, accounted for $43 \%$ of disc volume (15). The annulus fibrosus was modeled to be a composite of a homogenous ground substance strengthened by collagen fibers. The fiber content of annulus fibrosus accounted approximately for $19 \%$, which is appropriate to the natural collagen content of the annulus. The contact between facet joints was simulated using surface-to-surface contact elements without friction. With a gap of $0.5 \mathrm{~mm}$, the facet joints could only transmit compressive forces. The material constants for the normal healthy model were defined based on the previous literature (2) (Table I).

\section{Degenerative Models}

One mild degeneration model and one moderate degeneration model were developed based on the normal model. The mild and moderate degeneration disc had $20 \%$ and $40 \%$ height loss respectively, compared to the normal

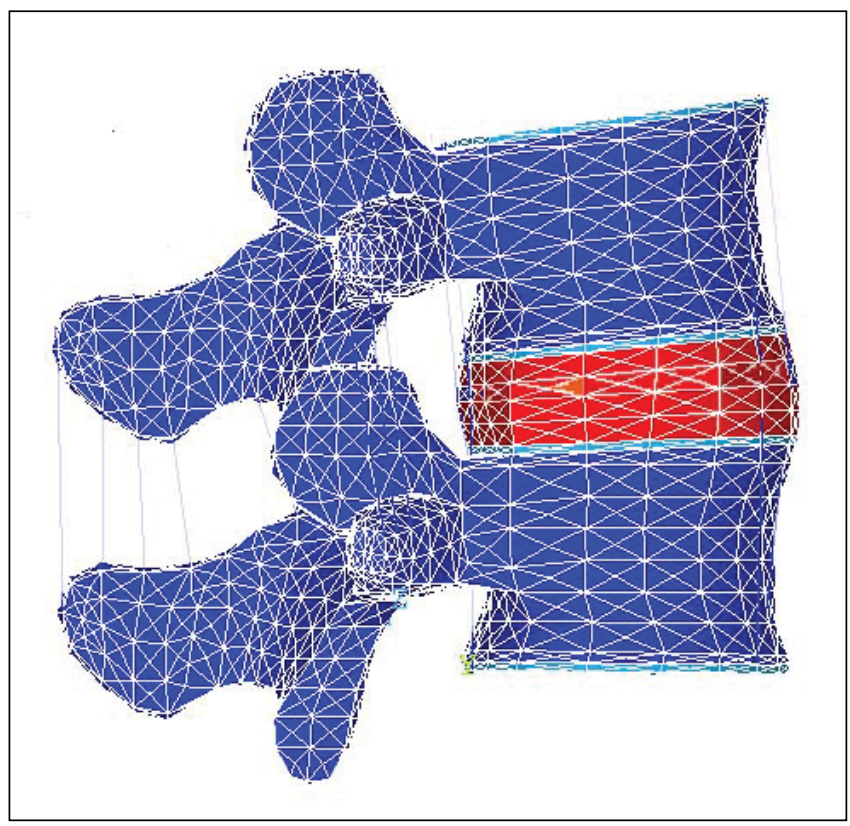

Figure 1: Normal, healthy finite element model of L4-5 segment.

Table I: The Material Properties in the Normal Model

\begin{tabular}{|l|c|c|c|}
\hline & Young's modulus (MPa) & Poisson's ratio & Element type \\
\hline Cortical bone & 12000 & 0.3 & Solid186 \\
\hline Cancellous bone & 100 & 0.2 & Solid186 \\
\hline Endplate & 500 & 0.25 & Solid186 \\
\hline Fibers & 92 & 0.45 & Solid186 \\
\hline Posterior elements & 3500 & 0.30 & Solid186 \\
\hline capsular ligament & 7.7 & 0.39 & Link10 \\
\hline anterior longitudinal ligament & 11.9 & 0.39 & Link10 \\
\hline posterior longitudinal ligament & 12.5 & 0.39 & Link10 \\
\hline ligamentum flavum & 2.4 & 0.39 & Link10 \\
\hline interspinous ligament & 3.4 & 0.39 & Link10 \\
\hline supraspinous ligament & 3.4 & 0.39 & Link10 \\
\hline transverse ligament & 3.4 & 0.39 & Link10
\end{tabular}


Table II: Material Properties for Annulus Ground Substance and Nucleus Pulposus

\begin{tabular}{l|c|c|c} 
& Normal Model & Mild Degeneration & Moderate Degeneration \\
\hline & $\mathrm{E}=0.9$ & $\mathrm{E}=1.07$ & $\mathrm{E}=1.25$ \\
& $\mathrm{C} 1=0.12$ & $\mathrm{C} 1=0.14$ & $\mathrm{C} 1=0.17$ \\
$\mathrm{C} 2=0.03$ & $\mathrm{C} 2=0.035$ & $\mathrm{C}=0.041$ \\
Annulus ground substance & $\mathrm{E}=1.35 \mathrm{MPa}$ & $\mathrm{E}=1.35 \mathrm{MPa}$ & $\mathrm{E}=1.35 \mathrm{MPa}$ \\
& $\mathrm{C} 1=0.18$ & $\mathrm{C} 1=0.18$ & $\mathrm{C} 1=0.18$ \\
& $\mathrm{C} 2=0.045$ & $\mathrm{C} 2=0.045$ & $\mathrm{C} 2=0.045$
\end{tabular}

C1,C2: Material constants characterizing the deviatoric deformation of the material; E: Young's modulus.

model (7). The corresponding Young's modulus was linearly interpolated. The $\mathrm{c} 1$ and $\mathrm{c} 2$ coefficients for two degenerative models came from previous literature (9). Disc degeneration was assumed to have no influence on the material properties of annulus ground substance (3) (Table II).

The endplate geometry of L4-5 in degenerative models was modified based on the previously accepted methods, i.e., we defined a range of $0 \%$ and $100 \%$ where $0 \%$ corresponded to the curvature of the normal, healthy disc and $100 \%$ corresponded to a planar, degenerative endplate, and the same percentages of changes in endplates, as we used for the disc height loss, were assumed in the degenerative models (9).

The decreased disc height leads to reduced length of the elements of ligamentous and capsular structures, in which all the parameters except interspinous and supraspinous ligaments were compensated by the offsetting of nonlinear stiffness curves in degenerative models (13).

\section{The Nucleotomy Models}

Nucleotomy was assumed to be carried out on the left, in which the left ligamentum flavum was removed, but the supraspinous ligaments, interspinous ligaments and posterior element were kept untouched. The material property of the nucleus pulposus was modified as those of the annulus ground substance (14). To facilitate the study, we assumed the annulus fibrosus was kept intact in two nucleotomy models.

\section{Boundary and Loading Conditions}

The inferior endplate of L5 was completely fixed. Combined with $800 \mathrm{~N}$ preloading, $10 \mathrm{Nm}$ moment of extension, flexion, left axial rotation and lateral bending moment were applied on the L4 superior endplate, respectively. The maximum load was applied in five steps, and the main parameters including shear stress of annulus fibrosus, posterior annulus bulge, and contact force of left facet joints at L4-5 segment were investigated.

\section{RESULTS}

The posterior annulus bulge of L4-5 in all models and loading directions is displayed in Figure 2. In all loading directions, the posterior annulus bulge in the moderately degenerative nucleotomy model was the lowest with $0.28 \mathrm{~mm}$ in flexion, $0.35 \mathrm{~mm}$ in extension, $0.33 \mathrm{~mm}$ in left lateral bending and 0.19 $\mathrm{mm}$ in left axial rotation, and the values in the normal model were the largest with $2.4 \mathrm{~mm}$ in flexion, $1.5 \mathrm{~mm}$ in extension, $0.9 \mathrm{~mm}$ in left lateral bending and $1.1 \mathrm{~mm}$ in left axial rotation. In all loading directions, the value of the posterior annulus bulge in the degenerative models was lower than in the normal model, but larger than in the nucleotomy models (Figure 2).

The shear stress of L4-5 annulus fibrosus in different models and loading directions is displayed in Figure 3. These are larger in moderately degenerative nucleotomy model in all loading directions than those in any other model, presenting with 1.23 $\mathrm{MPa}, 0.75 \mathrm{MPa}, 1.15 \mathrm{MPa}$ and $0.54 \mathrm{MPa}$ in the direction of flexion, extension, left lateral bending and axial rotation, respectively. The lowest values were found in the normal model, with $0.43 \mathrm{MPa}, 0.45 \mathrm{MPa}, 0.72 \mathrm{MPa}$ and $0.23 \mathrm{MPa}$ in flexion, extension, left lateral bending and axial rotation. In all loading directions, the shear stress in the degenerative models was larger than that in the normal model, but lower than that in the nucleotomy models (Figure 3).

The contact forces of the facet joint at L4-5 in different models and loading directions are displayed in Figure 4. The value was the highest in the moderately degenerative nucleotomy model and presented with 89.1 $\mathrm{N}$ in extension, $71.9 \mathrm{~N}$ in left lateral bending and $67.9 \mathrm{~N}$ in left axial rotation respectively. The contact forces in mildly degenerative nucleotomy model are lower than those in the moderately degenerative nucleotomy model, but larger than any other model in all loading directions (Figure 4).

\section{DISCUSSION}

In the current study, we performed a finite element study of L4-5 to determine whether nucleotomy might promote lumbar degeneration at the operated level. To the best of our knowledge, this is a unique study in the English literature, comparing biomechanical behaviors between different grades of degenerative lumbar models with corresponding nucleotomy models.

We found that the posterior annulus bulge decreased in nucleotomy models when compared to the normal or degenerative models. In a normal healthy intervertebral disc under compressive load, the annulus fibrosus is pressed by the nucleus pulposus, which makes the collagen fibers in the annulus fibrosus undertake loading in tension. When 


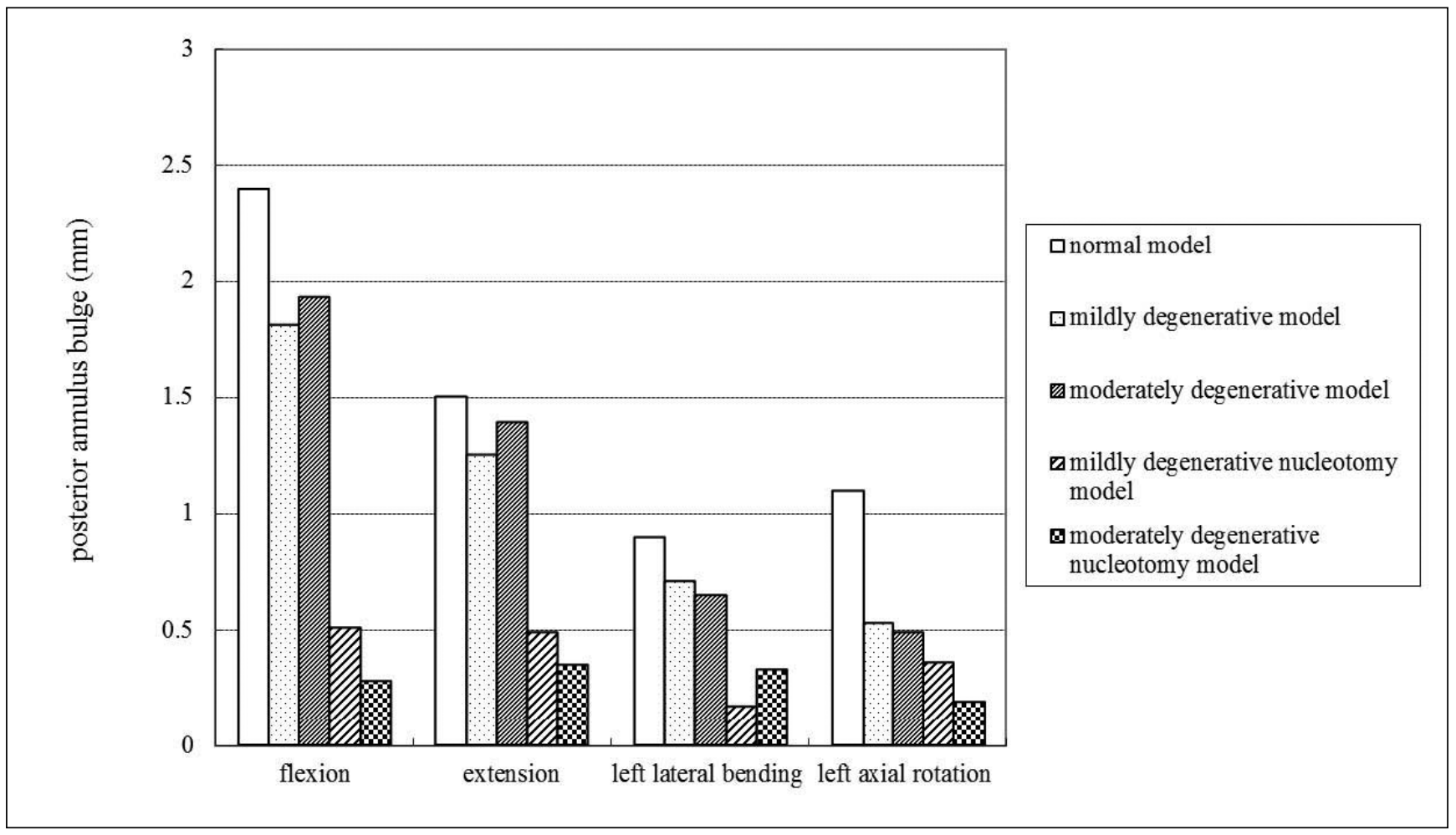

Figure 2: Posterior annulus bulge in different loading directions and models.

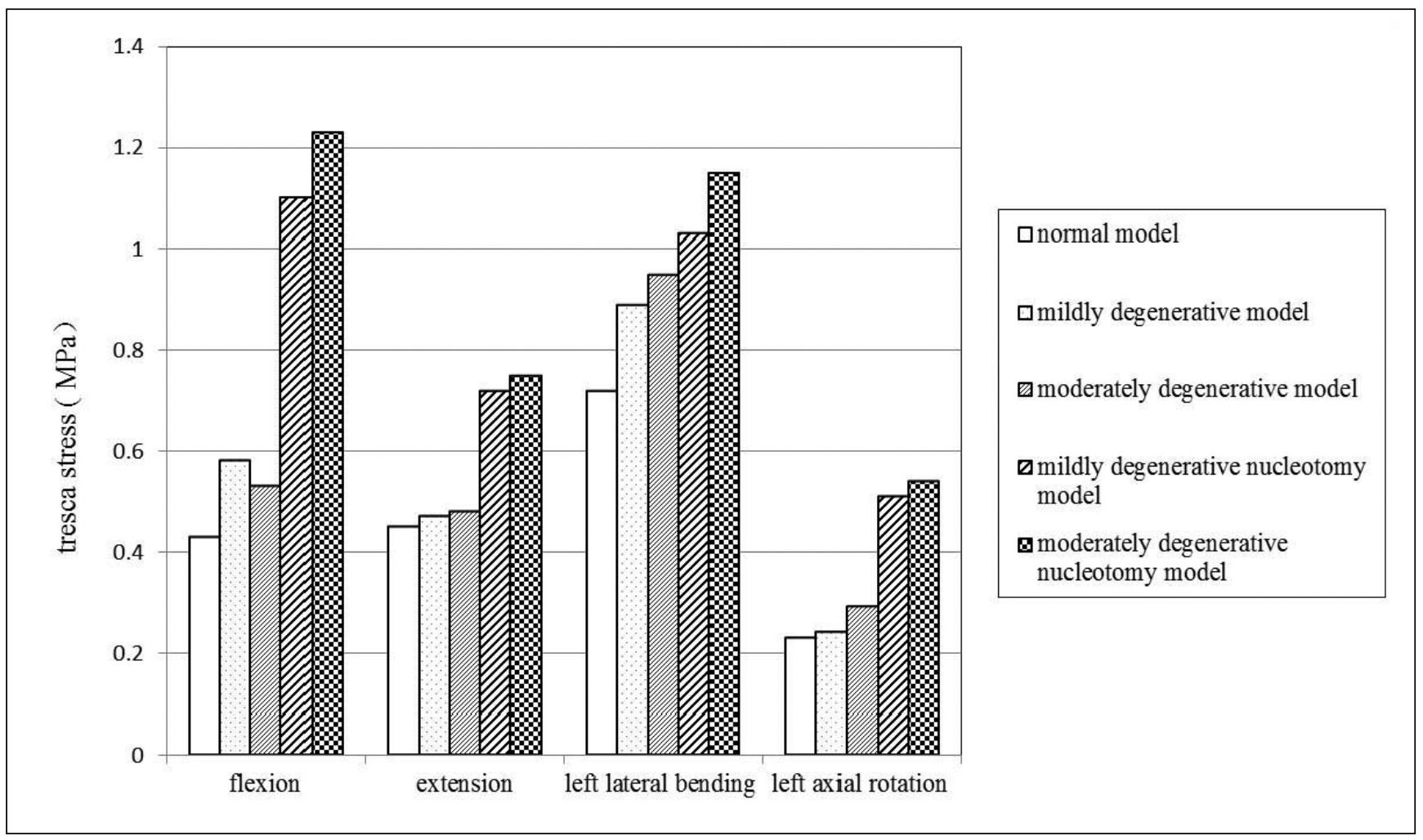

Figure 3: Shear stress of annulus fibrosus in different loading directions and models. 


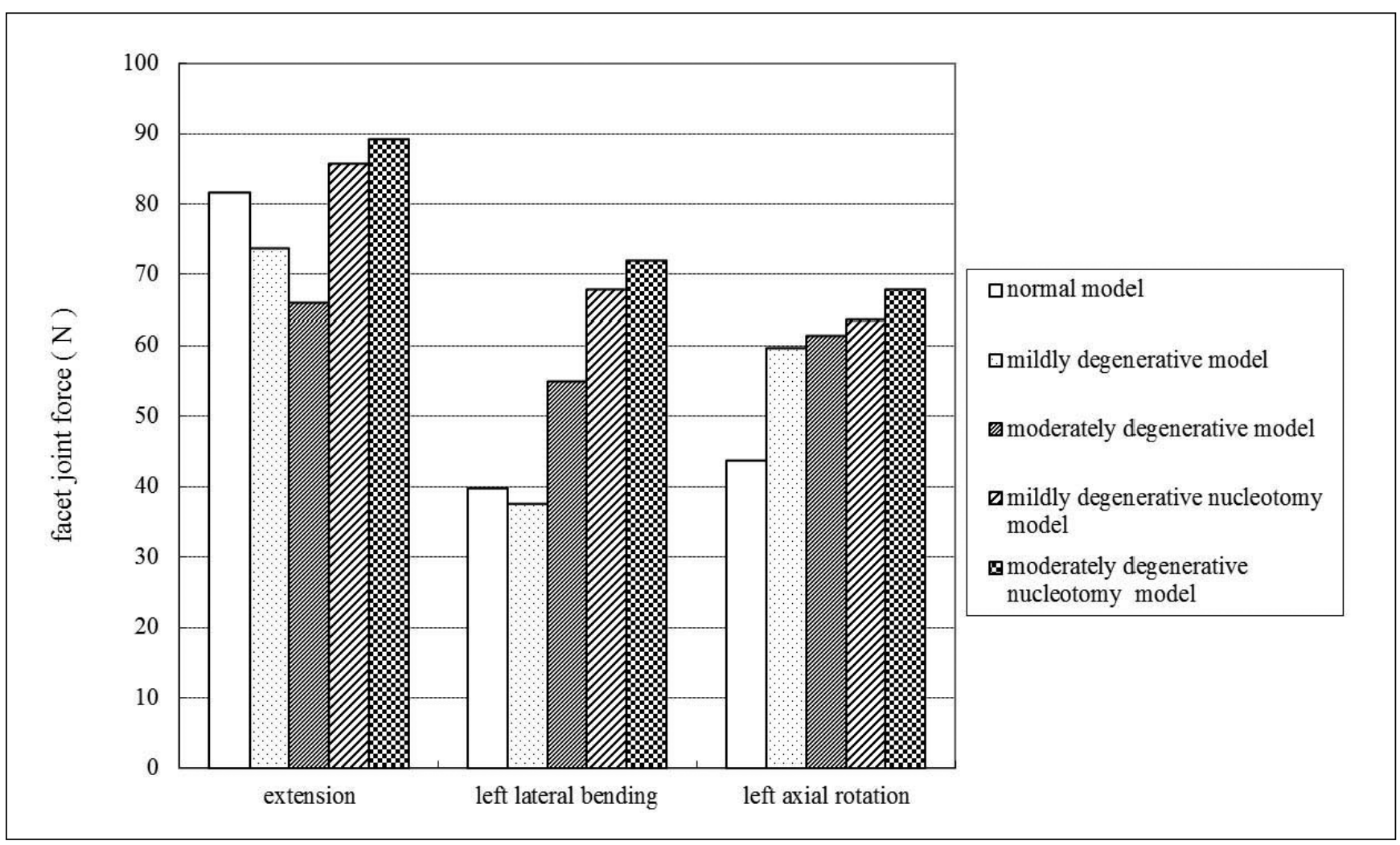

Figure 4: Contact force of facet joint in different loading directions and models.

the nucleus pulposus is replaced by granulation tissue, the biomechanical properties and load transfer modes will be changed, and the annulus fibrosus will carry more compressive forces and less tension (11). The decreased tension may result in the loosening and degeneration of annulus fibrosus. In the current study, the posterior bulge decreased from $1.81 \mathrm{~mm}$, $1.25 \mathrm{~mm}, 0.71 \mathrm{~mm}$ and $0.53 \mathrm{~mm}$ in the mildly degenerative model to $0.51 \mathrm{~mm}, 0.49 \mathrm{~mm}, 0.17 \mathrm{~mm}$ and $0.36 \mathrm{~mm}$ in the mildly degenerative nucleotomy model in flexion, extension, left lateral bending and left axial rotation respectively. The posterior bulge in the moderately degenerative nucleotomy model also presented with lower values when compared to the corresponding degenerative model. The results confirmed the abovementioned viewpoint and explained why the disc space height decreased with time after nucleotomy.

Moreover, the shear stress in the mildly degenerative nucleotomy model increased up to $89.7 \%, 53.2 \%, 15.7 \%$ and $121.7 \%$ in flexion, extension, left lateral bending and left axial rotation respectively, when compared to mildly degenerative model. The value increased from $0.53 \mathrm{MPa}, 0.48 \mathrm{MPa}, 0.95$ $\mathrm{MPa}$ and $0.29 \mathrm{MPa}$ in the moderately degenerative model to 1.23 MPa, 0.75 MPa, 1.15 MPa and 0.54 MPa in the moderately degenerative nucleotomy model, demonstrating a significant increase of shear stress in nucleotomy models. Along with the decreased posterior annulus bulge, we suggest that nucleotomy may adversely affect the degeneration of disc at the operated level.
In addition, the contact force of facet joints increased in the nucleotomy model when compared to corresponding degenerative models, demonstrating that nucleotomy may aggravate degeneration of the facet joint. Meanwhile, from the mildly degenerative nucleotomy model to moderately degenerative nucleotomy model, the contact force of L4-5 facet joint increased from $85.6 \mathrm{~N}, 67.8 \mathrm{~N}$ and $63.6 \mathrm{~N}$ to 89.1 $\mathrm{N}, 71.9 \mathrm{~N}$ and $67.9 \mathrm{~N}$ in extension, left lateral bending and left axial rotation respectively. When disc space height decreases, the stress on the lumbar spine may be affected, and as a result, the strain on the posterior columns and contact force of facet joints are increased. In addition, with the decrease of disc space height, the inferior facet of $L 4$ become oblique to the superior facet of $L 5$, which can also change the stress between facet surfaces (13). The decreased disc space height may be the explanation of the increase of the contact force of facet joints in the moderately degenerative nucleotomy model. Subsequently, we suggest that the decreased disc space height after nucleotomy may also aggravate the progress of degeneration of facet joints.

In some cases, although the difference of values between models is small, a clear trend is demonstrated, i.e., nucleotomy may adversely aggravate the lumbar degeneration at operated segment. However, our study does have inherent limitations. In the present study, we supposed the granulation tissue to occupy the nucleus pulposus space completely, while this may not be true in the clinical situation. In addition, the 
mechanical effect of muscle contraction was not accounted for and the loading conditions were not truly physiological. To further clarify these effects, more studies need to be carried out in the future.

\section{REFERENCES}

1. Dai $L Y, T u K Y, X u$ YK, Zhang WM, Cheng PL: Effects of discectomy on the stress distribution in the lumbar spine. Chin Med J (Engl) 105:944-948, 1992

2. Fantigrossi A, Galbusera F, Raimondi MT, Sassi M, Fornari M: Biomechanical analysis of cages for posterior lumbar interbody fusion. Med Eng Phys 29:101-109, 2007

3. Holzapfel GA, Schulze-Bauer CA, Feigl G, Regitnig P: Single lamellar mechanics of the human lumbar anulus fibrosus. Biomech Model Mechanobiol 3:125-140, 2005

4. Kotilainen $\mathrm{E}$, Alanen A, Erkintalo M, Valtonen S, Kormano M: Magnetic resonance image changes and clinical outcome after microdiscectomy or nucleotomy for ruptured disc. Surg Neurol 41:432-440, 1994

5. Mochida J, Toh E, Nomura T, Nishimura K: The risks and benefits of percutaneous nucleotomy for lumbar disc herniation. A 10-year longitudinal study. J Bone Joint Surg Br 83:501-505, 2001

6. O'Connell GD, Malhotra NR, Vresilovic EJ, Elliott DM: The effect of nucleotomy and the dependence of degeneration of human intervertebral disc strain in axial compression. Spine 36:1765-1771, 2011

7. Rohlmann A, Zander T, Schmidt H, Wilke HJ, Bergmann $\mathrm{G}$ : Analysis of the influence of disc degeneration on the mechanical behaviour of a lumbar motion segment using the finite element method. J Biomech 39:2484-2490, 2006
8. Saruhashi $Y$, Mori K, Katsuura A, Takahashi S, Matsusue $Y$, Hukuda S: Evaluation of standard nucleotomy for lumbar disc herniation using the Love method: Results of follow-up studies after more than 10 years. Eur Spine J 13(7):626-630, 2004

9. Schmidt $\mathrm{H}$, Kettler A, Rohlmann A, Claes L, Wilke HJ: The risk of disc prolapses with complex loading in different degrees of disc degeneration - a finite element analysis. Clin Biomech (Bristol, Avon) 22:988-998, 2007

10. Songer MN, Rauschning W, Carson EW, Pandit SM: Analysis of peridural scar formation and its prevention after lumbar laminotomy and discectomy in dogs. Spine 20:571-580, 1995; discussion 579-580

11. Strange DG, Fisher ST, Boughton PC, Kishen TJ, Diwan AD: Restoration of compressive loading properties of lumbar discs with a nucleus implant-a finite element analysis study. Spine J 10(7):602-609, 2010

12. Tang S, Meng X: Does disc space height of fused segment affect adjacent degeneration in ALIF? A finite element study. Turk Neurosurg 21:296-303, 2011

13. Tang S, Rebholz BJ: Does anterior lumbar interbody fusion promote adjacent degeneration in degenerative disc disease? A finite element study. J Orthop Sci 16(2):221-228, 2011

14. Tang S, Rebholz BJ: Does lumbar microdiscectomy affect adjacent segmental disc degeneration? A finite element study. J Surg Res 182:62-67, 2013

15. White III AA, Panjabi MM: Clinical Biomechanics of the Spine. Philadelphia: Lippincott Williams \& Wilkins, 1990 